\title{
INFLUENCE OF DANCE FITNESS-PROGRAMMS ON THE PHYSICAL PREPARATION OF THE STUDENTS IN CONDITIONS OF FACULTY LESSONS
}

\author{
Natalia Chuprun \\ Pereiaslav-Khmelnytskyi Hryhorii Skovoroda State Pedagogical University, Pereiaslav-Khmelnytskyi, Ukraine
}

\begin{abstract}
To explore the impact of dance fitness programs on the physical training of the students in conditions of faculty lessons. In the research took part the students of the pedagogical faculty of Pereiaslav-Khmelnytsky Hryhorii Skovoroda State Pedagogical University. $(n=30)$. It was revealed the interest of scientists in solving the problem of integration of choreography in physical education, but we want to admit the lack of scientific methodological developments in this direction. Using of modern fitness programs in dancing direction (Aero dance, Bodi Balet, Belly Dance) in physical education of students in conditions of faculty lessons is offered. The results of the research showed significant changes in the indicators of physical training, physical health, theoretical preparedness, which had occurred during the pedagogical experiment. It has been found that indicators students' physical state of experimental group substantially changed: ChSS from indicator $82,5 \mathrm{~b} / \mathrm{m}$ increased to 93,03 ; AP - from 120/70 to 130/90 mm.r.st., body mass declined from 63,1 to 60,15 $\mathrm{kg}$; tilt of the trunk forward from the sitting position $\mathrm{t}=7,77(\mathrm{p}<0,05)$; shuttle running $4 \mathrm{x} 9 \mathrm{~m} \mathrm{t}=4,82(\mathrm{p}<0,05)$; lifting the body in one minute $t=4,15(\mathrm{p}<0,05)$. It is proved that using of modern fitness programs of the dancing direction (Aero dance, Bodi Balet, Belly Dance) in the context of faculty lessons is an effective way to optimize the physical education of the students in order to solve the problems of their physical and intellectual development in a comprehensive way, satisfaction of motor activity needs, and to form a sustainable motivation to the lessons of physical education.
\end{abstract}

Key words: CHOREOGRAPHY / AEROBIC DANCE / BODI BALET / BELLY DANCE / PHYSICAL PREPARATION / FITNESS PROGRAMS / STUDENTS.

\section{INTRODUCTION}

The most actual problem of modern society is nation's health in general and the rising generation in particular. Especially acute this problem arises among young students - the most critical group of population, which include basis of future health and nation's beauty. The promising step in deciding problem of optimization the process of the student's physical education is using of the popular types of motor activity among students (Garkava, 2016).

About relevance and effectiveness of dancing exercises in the physical education tell native and foreign scientists. The place of dance in physical education, the interaction of choreography and physical education were researched (Angioi, 2009, Mattsson, 2015, Wang Bei, 2016). In particular, (Radaeva, 2015) affirms, that using choreographic exercises cause in the student higher interest to the physical training and further self-improvement. (Zubkov, 2006) made methodology of complex using of choreographic and gymnastic exercises on the faculty lessons of physical education for students of universities in the different degree of physical preparation. The scientist detected, that reliable improvement of indicators of physical features, ability of mood's improvement, higher interest of the students to the physical training, possibility full and consistent to decide tasks of physical education in the students of different degree of physical preparation, improving their emotional mood (Semeniv, 2016). Researches of Kravchuk and Rohanin (2015) show, that using dancing exercises in the process of the student's physical education at the universities promote considerable rising their 
physical health in general and improvement its separate indicators. Cone Stephen made a conclusion, that dance covers psychomotor (includes movements, which we can use during all life) cognitive (critical thinking) and affective (self-expressions) sphere of the people (Stephen, 2015). In this way it helps students to get success in studying and getting useless from life during all life, supporting active way of life (Bajek, 2015). Reseaarchers affirms, that dance can be important part of educational program, which promote studying psychomotor, cognitive and emotional skills, related with either physical activity and can integrates as a part of studying plan of physical education (Column Editor 2015). Problems of interplay and integration of physical education and choreography are showed in works of (Rafferty, 2010). Scientist admits gaps in the structure of the programs of dancer's preparation, which can fill with means of physical education and give recommendations of elimination gasps in the physical education with help of dance (Rafferty, 2010).

Therefore, coming out from above said, we assume, that mix modern fitness programs of dancing direction (Aerobic dance, Bodi Balet, Belly Dance) promote rising physical readiness of the students in conditions of faculty lessons.

Aim of the research - to explore an influence of modern fitness programs of dancing direction (Aaerobic dance, Bodi Balet, Belly Dance) on physical readiness of the students in conditions of faculty lessons.

\section{MATERIAL AND METHODS}

The research was based on Pereiaslav-Khmelnytsky Hryhorii Skovoroda State Pedagogical University. In the research took part 30 female students, aged 17-18 years, first year students of Pedagogical faculty. All students were divided for control and experimental groups, in every group for 15 students. Control group did according to the generally accepted technique, experimental group according to the experimental technique, which included different modern fitness programs of dance direction. The experiment lasted 4 months, from September to December 2017 year (First semester). Lessons were conducting twice a week - Tuesday (Aerobic dance) and Thursday (Bodi balet/ Belly Dance). Duration of the lesson 60 minutes. The experimental program, can be defined as training directed towards the development of cardiovascular endurance by using movement structures of aerobics, dance, aesthetically shaped choreography. Additionally, exercises for strength and flexibility development were performed. The training sessions consisted of three parts: the warm up (8 min), main part (45 min) and cool down (7 min). Every part of the training session was performed in accordance with the appropriate music; the music tempo during the warm up was $120-135$ beats per minute, while the main part was performed along to $125-155$ beats/min music tracks, and cool down to $60-90$ beats/min music tracks. General and specific warm ups were followed by the first part of the main part of the training session i.e. low intensity exercise (60-85\% of maximal heart rate). This part of the training was reserved for learning dance movements that are part of the choreography, while the second part of the main part of the training session was reserved for practicing the entire choreography at a high intensity ( $>85$ of HRmax).

Methods of the cognition: analyze and generalization of scientific and methodological literature and advanced pedagogical practice. In the process of conducting test guided by the same conditions for all participants, simplicity of measurements and evaluation, principle of accessibility for all students. Evaluation of physical readiness and definition the level of development of physical skills carried out with help of motor tests: tilt of the trunk forward (cm); Sit-Ups in 60 seconds - measures trunk strength (MLESED); $4 \times 9$ meter Shuttle Run - measures agility - 4x9m (s), running $30 \mathrm{~m}(\mathrm{~s})$, medical and biological: body weight $(\mathrm{kg}), \mathrm{BPs}$ and BPd (mmHg), ChSS (Apanasenko, 1995) in a state of rest and the Stange test (Malikov et al, 2006). All the data obtained by the study were processed by the procedures of descriptive and comparative statistical methods. From the area of the descriptive statistics the following parametres were defined: representative central and dispersive parametres: arithmetic average $-\bar{x} \pm m$; standard deviation $-\delta$; initial and final measuring. Unpaired t-test, applied in copmarative statistics, was perfomed in order to compare the arithmetic means of two independent data sets (experimental and control groups). Statistical analysis was performed by applying SPSS statistical software. 


\section{RESULTS AND DISCUSION}

Analyze, generalization and systematization educational methodical and special literature about problems of optimization and introduction into the educational process different means and methods of Physical education point to rising interest and active work of scientists in this way. In scientific literature are made assumptions, that for modern students defining condition of choosing form of the lessons in Physical training at the university is attractiveness of a program, its novelty, emotionality and popularity. For the purpose of exploring an influence of dance fitness programs on the student's physical preparation was conducted pedagogical experiment. In this research took part the first year students of Pedagogical faculty with the total number is 30 people. All participants of this experiment previously agreed to participate in experiment and data processing. Students were divided into control and experimental groups, in every group 15 students. Control group work according to the generally accepted technique, experimental group - according to the experimental program of lessons, which include mix of modern fitness programs with dancing direction - Aerobic dance (Viski-Stalec et al, 2007), Bodi balet (Bondarenko, 2006), Belly Dance (Blagoy, 2005). The experiment lasted 4 months, from September to December 2017 year (First semester). Lessons were conducting twice a week - Tuesday (Aerobic dance) and Thursday (Bodi balet, Belly Dance). Duration of the lesson was 60 minutes.

The results of own research confirm information, that corporal culture of dance provides deciding tasks, directed at optimization of motor activity depending on individual (Chuprun, 2018) and age-old features, rising functional possibilities (Pantelic et al, 2013) of a system and correction slight deviations of physical development and give a chance to consider dance exercises in the system of means of physical education different segments of the population .

The results of research's indicators morphed-functional students' state before and after experiment are listed in the table 1 and 2.

Table 1. Indicators morphed-functional students' state before experiment

\begin{tabular}{|c|c|c|c|c|c|}
\hline Group & $\bar{x} \pm m$ & $\delta$ & v & $\mathrm{t}$ & $\mathrm{p}$ \\
\hline \multicolumn{6}{|c|}{ Stange test, s } \\
\hline$C G$ & $39,65 \pm 2,57$ & 11,49 & 22,57 & & \\
\hline$E G$ & $37,25 \pm 2,41$ & 10,81 & 23,82 & 0,84 & 0,21 \\
\hline \multicolumn{6}{|c|}{ Body mass, $\mathrm{kg}$} \\
\hline$C G$ & $60,5 \pm 2,03$ & 7,09 & 16,26 & & \\
\hline$E G$ & $63,1 \pm 2,54$ & 11,39 & 19,26 & 1,04 & 0,43 \\
\hline \multicolumn{6}{|c|}{ BPs, mm.r.st. } \\
\hline$C G$ & $120,10 \pm 2,52$ & 11,26 & 9,97 & & \\
\hline$E G$ & $120,95 \pm 2,22$ & 9,93 & 8,64 & 1,33 & 0,55 \\
\hline \multicolumn{6}{|c|}{$\mathrm{BPd}, \mathrm{mm}$ r.st. } \\
\hline$C G$ & $70,85 \pm 1,77$ & 7,94 & 11,23 & & \\
\hline$E G$ & $75,15 \pm 1,87$ & 8,38 & 11,64 & 0,75 & 0,18 \\
\hline \multicolumn{6}{|c|}{ HB at rest, b./m. } \\
\hline$C G$ & $82,50 \pm 2,80$ & 10,54 & 15,03 & & \\
\hline$E G$ & $85,01 \pm 2,19$ & 9,79 & 11,91 & 0,77 & 0,17 \\
\hline
\end{tabular}

\footnotetext{
* - probability variance $\mathrm{p}<0,05$.
} 
Table 2. Indicators morphed-functional students' state after experiment

\begin{tabular}{|c|c|c|c|c|c|}
\hline Group & $\bar{x} \pm m$ & $\delta$ & v & $\mathrm{t}$ & $\mathrm{p}$ \\
\hline \multicolumn{6}{|c|}{ Stange test, s } \\
\hline$C G$ & $38,25 \pm 2,19$ & 9,82 & 17,57 & - & - \\
\hline$E G$ & $45,25 \pm 2,40 *$ & 9,95 & 17,85 & 1,50 & 0,030 \\
\hline \multicolumn{6}{|c|}{ Body mass $(\mathrm{kg})$} \\
\hline$C G$ & $58,42 \pm 1,90$ & 8,50 & 15,29 & - & - \\
\hline$E G$ & $60,15 \pm 1,88$ & 8,63 & 15,34 & 0,75 & 0,130 \\
\hline \multicolumn{6}{|c|}{ BPs, mm r.st. } \\
\hline$C G$ & $130,90 \pm 2,05$ & 9,19 & 8,07 & - & - \\
\hline$E G$ & $120,70 \pm 1,55^{*}$ & 6,93 & 5,99 & 1,65 & 0,557 \\
\hline \multicolumn{6}{|c|}{ BPd, mm r.st. } \\
\hline$C G$ & $80,05 \pm 1,17$ & 5,22 & 7,58 & - & - \\
\hline$E G$ & $73,70 \pm 1,18^{*}$ & 5,28 & 7,49 & 1,55 & 0,03 \\
\hline \multicolumn{6}{|c|}{$\mathrm{HB}$ at rest, b./m } \\
\hline$C G$ & $93,03 \pm 2,08$ & 9,31 & 11,86 & - & - \\
\hline$E G$ & $75,15 \pm 2,00 *$ & 9,01 & 10,17 & 1,71 & 0,01 \\
\hline
\end{tabular}

Note. Authenticity of difference $-{ }^{\star} \mathrm{p}<0,05,{ }^{* *}-\mathrm{p}<0,005$

The results of researches' indicators morphed-functional students' state show that indicators timed inspiratory capacity, body mass, blood pressure as control group, as experimental meet age standards and haven't probable differences. Exclusion was heart rate, which exceed normal values and was evaluated as moderate tachycardia. In our opinion, this phenomenon may be related with functional tension in work of students' cardiovascular system. To confirm the effectiveness this program was conducted the second research of indicators students' physical state of control and experimental groups in the end of experiment. From the table is visible that indicators students' physical state of experimental group substantially changed: ChSS from indicator $82,5 \mathrm{~b} / \mathrm{m}$ increased to 93,03 ; BP - from $120 / 75$ to $120 / 73$ mm.r.st., body mass declined from 63,1 to $60,15 \mathrm{~kg}$, indicator timed inspiratory capacity significantly hasn't changed.
In experimental group was discovered that great changes got thanks to such tests: tilt of the trunk forward from the sitting position (flexibility) $t=7,77$ $(\mathrm{p}<0,05)$; shuttle running $4 \times 9 \mathrm{~m}$ (agility) $\mathrm{t}=4,82$ $(\mathrm{p}<0,05)$; lifting the body in one minute (power) $\mathrm{t}$ $=4,15(\mathrm{p}<0,05)$. The fourth place according to rating - jump in length from place (high power quality) $t$ $=2,75$. Indicators of flexibility and agility allowed to show improvement in growth, which was $55,7 \%$ (in flexibility) and $49,3 \%$ (agility). This explain that in experimental group was used classical choreographic exercises, which carried out at the support and in the middle of the hall, tools for plasticity, rhythmic and dance exercises.

Indicators of testing running of girls for $30 \mathrm{~m}$ and $2000 \mathrm{~m}$ (table 3) in control and experimental groups didn't change and we can see slight improvement $t=$ $1,79(\mathrm{p}>0,05) \mathrm{t}=1,73 \rrbracket(\mathrm{p}>0,05)$. 
Table 3. Indicators level of the first year students' physical preparation after experiment

\begin{tabular}{|c|c|c|c|c|c|}
\hline № & & \multicolumn{4}{|c|}{ M easurement indicators } \\
\hline & & CG & $\mathrm{EG}$ & & $\mathrm{P}$ \\
\hline 1 & Running 30 m (s) & $4,9 \pm 0,04$ & $4,8 \pm 0,04$ & 1,79 & $>0,05$ \\
\hline 2 & Sit-Ups in 60s. (times) & $41,1 \pm 0,39$ & $43,9 \pm 0,55$ & 4,15 & $<0,05$ \\
\hline 3 & Jump in length from place (cm) & $183,91 \pm 2,9$ & $194,58 \pm 2,59$ & 2,75 & $<0,05$ \\
\hline 4 & Running at $2000 \mathrm{~m}(\mathrm{mn})$ & $10,38 \pm 0,12$ & $10,12 \pm 0,09$ & 1,73 & $>0,05$ \\
\hline 5 & Shuttle Run 4 x 9m (s) & $9,92 \pm 0,04$ & $9,65 \pm 0,04$ & 4,82 & $<0,05$ \\
\hline 6 & $\begin{array}{l}\text { Lift of the trunk forward from the sitting } \\
\text { position }(\mathrm{cm})\end{array}$ & $14,3 \pm 0,3$ & $18,0 \pm 0,37$ & 7,77 & $<0,05$ \\
\hline
\end{tabular}

The results of research showed great changes in indicators of physical readiness, physical health, theoretical readiness, which were during pedagogical experiment. The level of the students' physical health has risen, indicators of students' cardiovascular and respiratory systems became better. This coincide with researches of Stojanović-Tošić and associates (2011). Increase in the results occurred in the indicators of motor tests. Mostly changes were in indicators of coordination abilities. The same results got Viskić-Štalec and asoociates (2007) in accordance with their researches. Researches of Sibinović and associates (2011), Zagorc and associates (2000) confirm that aerobic exercises develop nearly all kinds of coordination.

\section{Conclusions}

Analyze of educational methodical literature and advanced modern world practice allow to make a conclusion about effectiveness joining different fitness programs of the students' physical education.

\section{REFERENCES}

1. Andrew, K., Richards, R. (2015). Benefits of Implementing a Dance Unit in Physical Education. Column Editor: Journal of Physical Education, Recreation \& Dance. 2015; 43-45

2. Angioi, M., Metsios, G.S., Twitchett E, Koutedakis, Y., Wyon, M. (2009). Association between selected physical fitness parameters and esthetic competence in contemporary dancers. J Dance Med Sci. 13(4):115-23

3. Bajek,M., Richards, K. A.,R., \& Ressler, J. (2015). Benefits of Implementing a Dance Unit in Physical Education. Strategies. A Journal for Physical
Dance movement is an effective mean of training human body is proved and can effectively use in the modern efficient technologies of study and education, which decide problems of physical and intellectual student's development, satisfaction needs in movement activity, formation resistant motivation to the Physical training. Accessibility, variety of means, forms, types of choreography improve successful enrichment of motor experience, and high emotional of lessons arise students' interest to systematic lessons of physical exercises.

\section{Acknowledgements}

The work has been fulfilled within the frames of applied scientific research «Theoretical methodological basis of formation sport style of growing up generations' life in Ukraine» (state registration number 0104U003129).

Conflict of interest: Authors state no conflict of interest.

Statement of Disclosure: research is not funded.

and Sport Educators. [serial on the Internet]. 2015 [cited 10 Sep 2015]; 28: 43-45. Available from: doi.org/10.1080/08924562.2015.1066613

4. Blagoy O. (2005). Features of using «Belly Dance» in modern fitness. Sport Newspaper Prydniprov'ia. 2: 112-114.

5. Blessing, D.L., Wilson, G.D., Puckett, J.R., Ford, H.T. (1987). The physiologic effects of eight week of aerobic dance with and without hand-held weights. The American Journal of Sports Medicine, 15 (5), 508-10 DOI: $10.1177 / 036354658701500515$ 
6. Bondarenko E.V. (2006). System of exercises body ballet as a full-fledged means of solving a number of problems of physical education of students of technical college. Actual questions of physical culture and sports: Materials of the IX All-Russian Scientific and Practical Conference 2006 March 30-31; Tomsk: TGPU; 105-109.

7. Chuprun, N. (2018). Modernization of Physical Education of Students by Means of Choreography on the Basis of an Integrated Approach. Physical Education, Sportsand Health Culture in Modern Society: 4-40:41- 45. DOI.org/10.29038/22207481-2017-04-41-45

8. Cone, S. L. (2015). An Innovative Approach to Integrating Dance into Physical Education. Journal of Physical Education, Recreation \& Dance. Pages 3-4 doi.org/10.1080/07303084.2015.1064669

9. Dobraš, R., Dragosavljević, P., Vučković, I., Gadžić,A., Lepir, D. (2013). The Impact of the Motivational Intervention on Students' motor abilities. Physical Culture; 67 (1): 24-32 doi.org/ $10.1080 / 08924562.2015 .1066613$

10. Garkava O.V. (2016). Use of the new format in practical classes on physical education at university. Scientific journal [MP Drahomanov National Pedagogical University]. 3 (2): 87-90.

11. Kravchuk T. M. (2015). Improvement possibilities of using dance exercises in physical education of students of higher educational institutions. Theory and methods of physical education. 02: $41-46$

12. Mandarić, S., Sibinović, A., Stojiljković, S. (2011). Effects of a High-Low aerobic program on the morphological features, functional and motor abilities of female elementary school eighth grades. Facta Universitatis, Series: Physical Education and Sport, 9(3), 307-319.

13. Pantelic, S., Milanovic, Z., Sporis, G. \& Stojanovic-Tosic, J. (2013). Effects of a twelve-week aerobic dance exercises on body compositions parameters in young women. Int. J. Morphol. 31(4):1243-1250.

14. Radaeva S.V. (2015). Application of choreographic exercises in physical education of students. Physical Culture, Public Health and Education: Materials of the IX International Scientific and Practical Conference devoted to the memory of VS Pirussky, 2015, November 19-20; Tomsk, 77-79
15. Rafferty S. (2010). Considerations for integrating fitness into dance training. J Dance Med Sci. 14(2):45-9.

16. Semeniv D.A. (2016). Modern approaches to the use of fitness programs in the physical education of students. Bulletin of the Baltic federal university them. I. Kant.Ser .: Philology, pedagogy, psychology. 4: 96-102.

17. Sibinovic, A., \& Mandaric, S. (2017). Effects of various group fitness programs on motor skills of the seventh grade female students in elementary school. Research in Kinesiology, 45(1), 25-30.

18. Sibinović, A., Mandarić, S., Mikalački, M., Stojiljković, S. (2011). Effects of high and low aerobics programme on motor abilities of the eighth grade elementary school students. Book of Proceesding: 6. kongres FIEP-a EUROPE „Tjelesna i zdravstvena kultura u 21. stoljeću - kompetencije učenika", str. 446-453. Poreč: Hrvatski kineziološki savez.

19. Stojanović-Tošić, J., Kostić, R., \& Đorđević, D. (2011). The effects of Kick aerobics on the fitness abilities of female high school studentes. Facta Universitatis, Series: Physical Education and Sport, 9(2), 113-120.

20. Torun Mattsson \& Suzanne Lundvall (2015). The position of dance in physical education. Sport, Education and Society. 20: 855-871 doi.org/10.10 80/13573322.2013.837044

21. Viskić-Štalec, N; Štalec, J., Katić, R., Podvorac, Đ., Katović, D. (2007). The Impact of Dance-Aerobics Training on the Morpho-Motor Status in Female High-Schoolers. Coll. Antropol. 31 ( 1): 259-266

22. Viski-Stalec, N., Stalec, J., Kati, R., Podvorac, D., \& Katovi, D. (2007). The Dance-Aerobics Training and the Morpho-Motor Status in Female. Coll. Antropol. (31): 259-266

23. Wang Bei (2016). Research on Body Language in Aerobics Choreography and Physical Education based on Network Questionnaire International. Journal of Future Generation Communication and Networking Vol. 9, No. 4, 207-218 doi. org/10.14257/ijfgen.2016.9.4.18

24. Zubkova T.I. (2006). Features of the use of choreographic exercises when working with students of varying degrees of preparedness. Theory and practice of physical culture. $4: 34$. 


\title{
INFLUENCIA DE LOS PROGRAMAS DE FITNESS A BASE DE BAILE EN LA PREPARACIÓN FÍSICA DE LOS ESTUDIANTES DE LA FACULTAD DE PEDAGOGÍA
}

\begin{abstract}
Resumen
El objeto del presente trabajo es la influencia de los programas de fitness a base de baile en el estatus físico-fitness de los estudiantes (N30) de la Universidad Estatal Jmelnitski Grygor Skovoroda. Los resultados obtenidos son de interés para los enseñadores investigadores en solución del problema de integrar coreografías en la educación física. Sin embargo, es importante destacar que hay una falta en el desarrollo científico-metodológico en esta dirección. Se ha presentado la aplicación de los programas de fitness modernos orientados hacia el baile (danza aeróbica, body ballet, danza del vientre) en la educación física de los estudiantes en las condiciones de conferencias de la facultad. Los resultados de las investigaciones demostraron importantes cambios en los indicadores de entrenamiento físico, salud física, como también en la preparación teórica que sucedieron durante el experimento pedagógico. Se ha establecido que los indicadores de estado físico de los estudiantes en el grupo experimental cambiaron considerablemente como sigue: CxSS indicador aumento de $82,5 \mathrm{~b} / \mathrm{m}$ a 93,03; tensión arterial se mantuvo inalterado, la masa corporal disminuyó de 63,1 a 60,15 kg; la inclinación hacia adelante en la posición sedentaria en $7,77 \mathrm{~cm}(\mathrm{r}<0,05)$; carrera de lanzadera $4 \times 9 \mathrm{~m}$ en $4,82 \mathrm{sec}(\mathrm{r}<0,05)$; levantamiento del cuerpo en un minuto en 4,15 subida $(\mathrm{r}<0,05)$. Se ha establecido que la aplicación de los programas modernos de fitness orientados hacia el baile que se realizan en contexto de la enseñanza universitaria es un modo eficiente de optimizar el programa de la educación física de los estudiantes para que los problemas de su desarrollo físico e intelectual se solucionaran de una manera multifacética, satisfaciendo las necesidades de actividades motrices, pero también para desarrollar una motivación sostenible en las clases de la educación física.
\end{abstract}

Palabras claves; COREOGRAFÍA / DANZA AERÓBICA / BODY BALLET / DANZA DEL VIENTRE/ PREPARACIÓN FÍSICA / PROGRAMAS DE FITNESS / ESTUDIANTES

Reacived: 20.05. 2018

Accepted: 05. 06. 2018 


\title{
УТИЦАЈ ПЛЕСНИХ ФИТНЕС ПРОГРАМА НА ФИЗИЧКУ ПРИПРЕМЉЕНОСТ СТУДЕНАТА ПЕДАГОШКОГ ФАКУЛТЕТА
}

\author{
Наталиа Чупрун
}

Перислав-Кмелнутски Хрухори Сковорода Државни педагошки универзитет, Периаслав-Кмелнутски, Украјина

\begin{abstract}
Сажетак
Предмет овог рада је утицај плесних фитнес програма на физички - фитнес статус студената $(\mathrm{H}=30)$ Државног педагошког универизитета Кмелнутски Хрухори Сковорода. Добијени резултати су интересантни за наставнике истраживаче у решавању проблема интегрисања кореографије у физичко васпитање. Ипак, важно је истаћи да постоји недостатак у научно-методолошком развоју у том правцу. Представљена је примена модерних фитнес програма оријентисаних на плес (плесни аеробик, боди балет, трбушни плес) у физичком васпитању студената у условима факултетских предавања. Резултати истраживања су показали значајне промене у показатељима физичког тренинга, физичког здравља, као и теоретске припреме, које су се догодиле током педагошког експеримента. Утврђено је да су се показатељи физичког стања студената у експерименталној групи значајно променили, и то: ЦхСС показатељ се повећао са 82,5 б/м на 93,03; крвни притисак је остао непромењен, телесна маса се смањила са 63,1 на 60,15 кг; претклон напред у седећем положају за 7,77цм

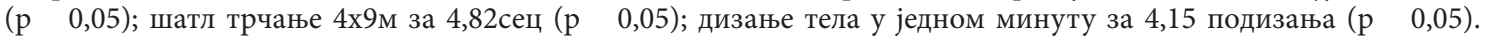
Утврђено је да је примена модерних фитнес програма оријентисаних ка плесу, који се реализују у контексту факултетске наставе, ефикасан начин да се оптимизује програм физичког васпитања студената. На тај начин би се проблеми њиховог физичког и интелектуалног развоја решили на свеобухватан начин, задовољиле потребе за моторичким активностима, али би се развила и одржива мотивација на часовима физичког васпитања.
\end{abstract}

КљУчне речИ: КОРЕОГРАФИЈА / АЕРОБИК ПЛЕС / БОДИ БАЛЕТ / ТРБУШНИ ПЛЕС / ФИЗИЧКА ПРИПРЕМА / ФИТНЕС ПРОГРАМИ / СТУДЕНТИ

\section{УВОД}

Најактуелнији проблем савременог друштва је здравље појединца, нарочито генерација које тек одрастају. Као посебно озбиљан проблем је стање младих - студената, који су најкритичнија група будућег „здравља и лепоте“ нације. Обећавајући корак у решавању овог проблема је оптимизација процеса физичког васпитања студената кроз примену оних врста моторичких активности које су популарне међу студентима (Garkava, 2016).

Украјински и страни научници говоре о значају и ефикасности плесних вежби у физичком васпитању и образовању. Место које плес заузима у физичком васпитању, као и интеракција измеЂу кореографије и физичког васпитања, је предмет овог истраживања (Angion, 2009; Mattson, 2015; Wang Bei, 2016). Потврђено је да употреба кореографских вежби доводи до повећаног интересовања студената за физички тренинг и даљи развој (Radaeva, 2015). Зубков (2006) је сачинио методологију сложене примене кореографских и гимнастичких вежби у оквиру факултетске наставе физичког васпитања за студенте универзитета различитих нивоа физичке припремљености. Он је поуздано утврдио побољшање показатеља физичких карактеристика, атрибута расположења, повећану заинтересованост за вежбање, спремност за потпуно и конзистентно решавање задатака физичког васпитања код студената на различитим нивоима физичке припремљености, што побољшава њихово емоционално расположење (Semeniv, 2016). Истраживање Кравчука и Роханина (2015) показују да примена плесних вежби у процесу физичког васпитања студената у значајној мери доприноси побољшању њиховог 
физичког здравља уопште, као и побољшању њихових засебних показатеља. Стефен је дошао до закључка да плес покрива психомоторне (укључујући покрете које користимо током читавог живота), когнитивне (критичко мишљење) и афективне (самоизражавање) сфере човека (Stephen, 2015). На специфичан начин плес помаже студентима да постигну успех у учењу током читавог живота, подржавајући активни стил живота (Bajek, 2015). Истраживачи потврђују да плес може да буде значајан део образовног програма, којим се промовише развој психомоторних, когнитивних и емоционалних вештина, повезаних са физичком активношћу и да се сходно томе може интегрисати као део наставног плана физичког васпитања (Колумна Уредника, 2015). Проблеми узајамног односа и интеграције физичког васпитања и кореографије приказани су у радовима Рафертија (2010). Ипак, истраживачи признају да постоје празнине у структури програма за припрему плесача, које се могу попунити путем физичког васпитања и дају препоруке за отклањање недостатака у физичком васпитању помоћу садржаја плеса (Rafferty, 2010).

Дакле, на основу горе наведеног, може се претпоставити да мешавина модерних фитнес програма оријентисаних на плес (плесни аеробик, боди балет, трбушни плес) промовишу повећање физичке спремности студената у условима факултетских предавања.

Циљ истраживања - испитати утицај модерних фитнес програма оријентисаних на плес (плесни аеробик, боди ठалет, трбушни плес) на физичку спремност студената у условима факултетских предавања.

\section{МАТЕРИЈАЛ И МЕТОДЕ}

Истраживање је спроведено на Државном педагошком универзитету Перислав-Кмелнутски Хрухори Сковорода. У истраживању је учествовало 30 девојака, старости 17-18 година, студенткиња прве године педагошког факултета. Узорак је подељен на контролну и експерименталну групу. У свакој групи је било по 15 студенткиња. Контролна група је радила по опште прихваћеном програму, док је експериментална група вежठала према експерименталном програму који је обухватио различите модерне фитнес програ- ме оријентисане на плес. Експеримент је трајао 4 месеца, од септембра до децембра 2017. године (први семестар). Вежбања су одржавана два пута недељно - уторком (плесни аеробик) и четвртком (боди балет/ трбушни плес). Дужина вежбања је износила 60 минута. Експериментални програм је дефинисан као тренинг усмерен ка развоју кардиоваскуларне издржљивости помоћу примене аеробика, плеса и естетски обликоване кореографије. Поред тога, извођене су вежбе за развој снаге и гипкости. Појединачни тренинзи су се састојали од три дела: загревање (8 мин), главни део (45 мин) и завршни део (7 мин). Сваки део тренинга је извођен уз одговарајућу музику; темпо музике током загревања је био 120-135 откуцаја у минуту, док је главни део извођен уз музичке нумере у темпу 125-155 откуцаја у минуту, а завршни део уз музичке нумере у темпу од 60-90 откуцаjа у минуту. Општа и специфична загревања су праћена првим делом главног дела тренинга, тј. вежठама малог интензитета (60-85\% максималне фреквенције срца- ФСмах). Овај део тренинга је био резервисан за плесне покрете и кретања који су део кореографије, док је други део главног дела тренинга био резервисан за увежбавање читаве кореографије при високом интензитету (>85 ФСмах).

\section{Методе сазнања и мерења}

У раду су примењене анализа и генерализација научне и методичке литературе и напредне педагошке праксе. У процесу спровођења теста у истим условима за све учеснике, примењени су једноставност мерења и евалуације, као и принцип приступачности за све студенте. Оцена физичке спремности и дефинисање нивоа развоја физичких способности спроведени су помоћу моторичких тестова: претклон трупом унапред (цм); трбушњаци у 60 секунди - којима се мери снага трупа (МЛЕСЕД); 4x9 метара „шатл“ трчање - којим се мери агилност - 4x9м (c), трчање на 30 м (c) и 2000м (мин). Простор биомедицинских мерења обухватио је телесну тежину (кг), крвни притисак - систолни и дијастолни (mmHG), CxSS у стању мировања, и тест Стангеа (Malikov et al, 2006). Сви подаци су обрађени поступцима дескриптивне и компаративне статистике. Из области дескриптивне статистике, дефинисани су: репрезентативни централни и дисперзивни параметри: аритметичка средина $\bar{x} \pm m$; стандард- 
на девијација $\delta$ иницијалног и финалног мерења. Т-тест за неупарене узорке, који се примењује у компаративној статистици, спроведен је како би се упоредиле аритметичке средине два независна скупа података (експерименталне и контролне групе). Статистичка анализа је извршена помоћу СПСС статистичког софтвера.

\section{РЕЗУЛТАТИ И ДИСКУСИЈА}

Анализа, генерализација и систематизација образовне методичке и специјалистичке литературе о проблемима оптимизације и увођења различитих средстава и метода физичког васпитања у образовни процес указују на повећану заинтересованост и активан рад истраживача у овом правцу. У научној литератури постоје претпоставке да студенти на универзитетима сматрају да је дефинисање услова садржаја програма часова у оквиру физичког васпитања део атрактивности програма, његове иновативности, емоционалности и популарности.

У сврху истраживања утицаја плесних фитнес програма на физичку спремност студената спроведен је педагошки експеримент. Сви учесници су претходно дали свој пристанак да учествују у експерименту, као и на обраду података. Студенти су подељени у контролну и експерименталну групу, где је у свакој групи било по 15 студената. Контролна група је радила у складу са опште прихваћеном техником, а експериментална група према експерименталном наставном програму, који обухвата мешавину модерних фитнес програма усмерених на плес - плесни аеробик (Viski - Stalec et al, 2007), боди балет (Bondarenko, 2006), трбушни плес (Blagoy, 2005).

Резултати овог истраживања потврђују податке да телесна култура плеса обезбеђује решавање задатака, усмерених на оптимизацију моторичких активности у зависности од појединца (Chypryn, 2018) и карактеристика повезаних са старосним узрастом, повећавајући функционалне могућности (Пантелић и сар., 2013) система и корекцију благих девијација у физичком развоју, а пружају и могућност да се размотри увођење плесних вежби у систем наставе физичког васпитања у различитим сегментима код различите популације. Показатељи морфолошко-функционалног стања студената пре и након експеримента дати су у табелама 1 и 2.

Табела 1. Показатељи морфо-функционалног статуса студената пре експерименталног фактора

\begin{tabular}{|c|c|c|c|c|c|}
\hline Група & $\bar{x} \pm m$ & $\delta$ & $\mathrm{v}$ & $\mathrm{t}$ & $\mathrm{p}$ \\
\hline \multicolumn{6}{|c|}{ Тест Стангеа, s } \\
\hline КГ & $39,65 \pm 2,57$ & 11,49 & 22,57 & & \\
\hline $\mathrm{E} \Gamma$ & $37,25 \pm 2,41$ & 10,81 & 23,82 & 0,84 & 0,21 \\
\hline \multicolumn{6}{|c|}{ Телесна тежина, kg } \\
\hline КГ & $60,5 \pm 2,03$ & 7,09 & 16,26 & & \\
\hline $\mathrm{E} \Gamma$ & $63,1 \pm 2,54$ & 11,39 & 19,26 & 1,04 & 0,43 \\
\hline \multicolumn{6}{|c|}{ Крвни притисак - систолни, $\mathrm{mm} . \mathrm{Hg}$} \\
\hline КГ & $120,10 \pm 2,52$ & 11,26 & 9,97 & & \\
\hline $\mathrm{E} \Gamma$ & $120,95 \pm 2,22$ & 9,93 & 8,64 & 1,33 & 0,55 \\
\hline \multicolumn{6}{|c|}{ Крвни притисак, дијастолни, $\mathrm{mm} \mathrm{Hg}$} \\
\hline $\mathrm{K} \Gamma$ & $70,85 \pm 1,77$ & 7,94 & 11,23 & & \\
\hline $\mathrm{E} \Gamma$ & $75,15 \pm 1,87$ & 8,38 & 11,64 & 0,75 & 0,18 \\
\hline \multicolumn{6}{|c|}{ Пулс у мировању, b./m. } \\
\hline КГ & $82,50 \pm 2,80$ & 10,54 & 15,03 & & \\
\hline $\mathrm{E} \Gamma$ & $85,01 \pm 2,19$ & 9,79 & 11,91 & 0,77 & 0,17 \\
\hline
\end{tabular}

Легенда: КГ - контролна група, ЕГ - експериментална група; варијанса вероватноће p<0,05. 
Чупрун Н., Утицај плесних фитнес програма на физичку припремљеност..., ФИЗИЧКА КУЛТУРА 2018; 72 (1): 89-95

Табела 2. Показатељи морфо-функционалног стања студената након експерименталног фактора

\begin{tabular}{|c|c|c|c|c|c|}
\hline Група & $\bar{x} \pm m$ & $\delta$ & $\mathrm{v}$ & $\mathrm{t}$ & $\mathrm{p}$ \\
\hline \multicolumn{6}{|c|}{ Тест Стангеа, s } \\
\hline КГ & $38,25 \pm 2,19$ & 9,82 & 17,57 & - & - \\
\hline $\mathrm{E} \Gamma$ & $45,25 \pm 2,40^{*}$ & 9,95 & 17,85 & 1,50 & 0,030 \\
\hline \multicolumn{6}{|c|}{ Телесна тежина, kg } \\
\hline КГ & $58,42 \pm 1,90$ & 8,50 & 15,29 & - & - \\
\hline $\mathrm{E} \Gamma$ & $60,15 \pm 1,88$ & 8,63 & 15,34 & 0,75 & 0,130 \\
\hline \multicolumn{6}{|c|}{ Крвни притисак - систолни, mm.Hg } \\
\hline КГ & $130,90 \pm 2,05$ & 9,19 & 8,07 & - & - \\
\hline $\mathrm{E} \Gamma$ & $120,70 \pm 1,55^{*}$ & 6,93 & 5,99 & 1,65 & 0,557 \\
\hline \multicolumn{6}{|c|}{ Крвни притисак, дијастолни, $\mathrm{mm} \mathrm{Hg}$} \\
\hline КГ & $80,05 \pm 1,17$ & 5,22 & 7,58 & - & - \\
\hline $\mathrm{E} \Gamma$ & $73,70 \pm 1,18^{*}$ & 5,28 & 7,49 & 1,55 & 0,03 \\
\hline \multicolumn{6}{|c|}{ Пулс у мировању, b./m. } \\
\hline КГ & $93,03 \pm 2,08$ & 9,31 & 11,86 & - & - \\
\hline ЕГ & $75,15 \pm 2,00 *$ & 9,01 & 10,17 & 1,71 & 0,01 \\
\hline
\end{tabular}

Аутентичност разлике- ${ }^{*} \mathrm{p}<0,05,{ }^{* *}-\mathrm{p}<0,005$

Резултати истраживања морфо-функционалног стања студената показују да временски мерени респираторни капацитет, телесна тежина, крвни притисак, како код контролне тако и код експерименталне групе задовољавају стандарде према узрасту и нема потенцијалних разлика. Изузетак је пулс који је прекорачио нормалне вредности и оцењен је као умерена тахикардија. По мишљењу аутора, ова појава се може повезати са функционалном тензијом у раду кардиоваскуларног система студената. Како би се потврдила ефикасност експерименталног фактора, спроведено је друго мерење показатеља физичког стања студената контролне и експерименталне групе на крају експеримента. Из табеле 3 се може видети да су се показатељи физичког стања студената у експерименталној групи значајно променили: ЦхСС показатељ се повећао са 82,5 $\delta /$ м на 93,03; крвни притисак - са 120/75 на 120/73 mmHG.; телесна тежина се смањила са 63,1 на 60,15 кг; показатељи временски мереног удисајног капацитета се нису значајно променили.
У експерименталној групи је утврђено да је до промена дошло, поред осталог и захваљујући резултатима на моторичким тестовима, и то: претклон трупом унапред из седећег положаjа (гипкост) за 7,77цм ( < 0,05); „шатл“ трчање 4x9m (агилност) за 4,82 сец ( $<0,05)$; подизање трупа за један минут (снага) за 4,15 понављања (p $<0,05)$. Четврто рангирани фактор је скок у даљ из места (висок квалитет испољавања снаге) за 2,75цм. Показатељи гипкости и агилности су довели до закључка о прирасту способности које је износило 55,7 \% (гипкост) и 49,3\% (агилност).

Добијени резултати моторичког простора говоре у прилог утицаја експерименталног програма кореографских вежби које су извођене помоћу вежби и реквизита за развој гипкости, ритмичких и плесних вежбања. Показатељи трчања на 30м и 2000м (Табела 3), у обе групе, нису се променили, иако се региструје статистички незначајно благо повећање $t=1,79(\mathrm{p}>0,05) \mathrm{T}=1,73(\mathrm{p}>0,05)$. 
Чупрун Н., Утицај плесних фитнес програма на физичку припремљеност..., ФИЗИЧКА КУЛТУРА 2018; 72 (1): 89-95

Табела 3. Показатељи физичке спремности студенткиња након спроведеног експеримента

\begin{tabular}{|c|c|c|c|c|c|}
\hline \multicolumn{2}{|c|}{ Тестови } & \multicolumn{3}{c|}{ Резултати мерења } \\
\hline \multicolumn{2}{|c|}{} & КГ & ЕГ & \multicolumn{2}{c|}{ p } \\
\hline 1 & Трчање на 30 м (s) & $4,9 \pm 0,04$ & $4,8 \pm 0,04$ & 1,79 & $>0,05$ \\
\hline 2 & Трбушњаци 60 s (број понављања) & $41,1 \pm 0,39$ & $43,9 \pm 0,55$ & 4,15 & $<0,05$ \\
\hline 3 & Скок у даљ из места (cm) & $183,91 \pm 2,9$ & $194,58 \pm 2,59$ & 2,75 & $<0,05$ \\
\hline 4 & Трчање на 2000m (min) & $10,38 \pm 0,12$ & $10,12 \pm 0,09$ & 1,73 & $>0,05$ \\
\hline 5 & Шатл трчање 4 х 9м (s) & $9,92 \pm 0,04$ & $9,65 \pm 0,04$ & 4,82 & $<0,05$ \\
\hline 6 & Претклон трупом у седећем положају $(\mathrm{cm})$ & $14,3 \pm 0,3$ & $18,0 \pm 0,37$ & 7,77 & $<0,05$ \\
\hline
\end{tabular}

Резултати истраживања су показали значајне промене у показатељима физичке спремности, али и простору теоријске припремљености, током овог педагошког експеримента. Параметри физичког здравља студената су се побољшали, показатељи кардиоваскуларног и респираторног система студената су ефикаснији. У овоме се слаже са резултатима истраживања Стојановић-Тошић и сарадници (2011). Побољшање у резултатима се догодило код показатеља моторичких тестова. Већина промена се одразила на показатеље опште-плесне координације. Исте резултате су добили Вискић-Шталец и сарадници (2007). Истраживачи Сибиновић и сарадници (2011), Загорц и сарадници (2000) потврђују да вежбе аеробика развијају готово све врсте координације.

\section{ЗАКЉУЧАК}

Анализа методичке литературе и напредна савремена пракса дозвољавају да се изведе закључак о ефикасности спајања различитих фитнес

\section{ЛИТЕРАТУРА}

1. Andrew, K., Richards, R. (2015). Benefits of Implementing a Dance Unit in Physical Education. Column Editor: Journal of Physical Education, Recreation \& Dance. 2015; 43-45

2. Angioi, M., Metsios, G.S., Twitchett E, Koutedakis, Y., Wyon, M. (2009). Association between selected physical fitness parameters and esthetic competence in contemporary dancers. J Dance Med Sci. 13(4):115-23

3. Bajek,M., Richards, K. A.,R., \& Ressler, J. (2015). Benefits of Implementing a Dance Unit in Physical Education. Strategies. A Journal for Physical and Sport Educators. [serial on the Internet]. програма и физичког васпитања и образовања студената. Плесни покрети су доказано средство тренинга човековог тела и могу се ефикасно користити у модерним образовним програмима, јер се истима решавају и проблеми и питање физичког и интелектуалног развоја студената, задовољава се њихова потреба за физичким активностима које стварају трајну мотивацију за физички тренинг. Доступност, широк спектар средстава, облика, врста и форми кореографије доприносе обогаћивању моторичког искуства, док практична предавања са високим емоционалним садржајем повећавају интересовање студената за часове физичког васпитања.

\section{Захвалност}

Овај рад је део примењеног научно истраживачког пројекта «Теоријско-методолошка основа за формирање спортског стила живота генерација које одрастају у Украјини» (број у државном регистру 0104У003129).

2015 [cited 10 Sep 2015]; 28: 43-45. Available from: doi.org/10.1080/08924562.2015.1066613

4. Blagoy O. (2005). Features of using «Belly Dance» in modern fitness. Sport Newspaper Prydniprov'ia. 2: 112-114.

5. Blessing, D.L., Wilson, G.D., Puckett, J.R., Ford, H.T. (1987). The physiologic effects of eight week of aerobic dance with and without hand-held weights. The American Journal of Sports Medicine, 15 (5), 508-10 DOI: 10.1177/036354658701500515

6. Bondarenko E.V. (2006). System of exercises body ballet as a full-fledged means of solving 
a number of problems of physical education of students of technical college. Actual questions of physical culture and sports: Materials of the IX All-Russian Scientific and Practical Conference 2006 March 30-31; Tomsk: TGPU; 105-109.

7. Chuprun, N. (2018). Modernization of Physical Education of Students by Means of Choreography on the Basis of an Integrated Approach. Physical Education, Sportsand Health Culture in Modern Society: 4-40:41- 45. DOI.org/10.29038/22207481-2017-04-41-45

8. Cone, S. L. (2015). An Innovative Approach to Integrating Dance into Physical Education. Journal of Physical Education, Recreation \& Dance. Pages 3-4 doi.org/10.1080/07303084.2015.1064669

9. Dobraš, R., Dragosavljević, P., Vučković, I., Gadžić,A., Lepir, D. (2013). The Impact of the Motivational Intervention on Students' motor abilities. Physical Culture; 67 (1): 24-32 doi.org/ $10.1080 / 08924562.2015 .1066613$

10. Garkava O.V. (2016). Use of the new format in practical classes on physical education at university. Scientific journal [MP Drahomanov National Pedagogical University]. 3 (2): 87-90.

11. Kravchuk T. M. (2015). Improvement possibilities of using dance exercises in physical education of students of higher educational institutions. Theory and methods of physical education. 02: 41-46

12. Mandarić, S., Sibinović, A., Stojiljković, S. (2011). Effects of a High-Low aerobic program on the morphological features, functional and motor abilities of female elementary school eighth grades. Facta Universitatis, Series: Physical Education and Sport, 9(3), 307-319.

13. Pantelic, S., Milanovic, Z., Sporis, G. \& Stojanovic-Tosic, J. (2013). Effects of a twelve-week aerobic dance exercises on body compositions parameters in young women. Int. J. Morphol. 31(4):1243-1250.

14. Radaeva S.V. (2015). Application of choreographic exercises in physical education of students. Physical Culture, Public Health and Education: Materials of the IX International Scientific and Practical Conference devoted to the memory of VS Pirussky, 2015, November 19-20; Tomsk, 77-79

15. Rafferty S. (2010). Considerations for integrating fitness into dance training. J Dance Med Sci. 14(2):45-9.
16. Semeniv D.A. (2016). Modern approaches to the use of fitness programs in the physical education of students. Bulletin of the Baltic federal university them. I. Kant.Ser .: Philology, pedagogy, psychology. 4: 96-102.

17. Sibinovic, A., \& Mandaric, S. (2017). Effects of various group fitness programs on motor skills of the seventh grade female students in elementary school. Research in Kinesiology, 45(1), 25-30.

18. Sibinović, A., Mandarić, S., Mikalački, M., Stojiljković, S. (2011). Effects of high and low aerobics programme on motor abilities of the eighth grade elementary school students. Book of Proceesding: 6. kongres FIEP-a EUROPE „Tjelesna i zdravstvena kultura u 21. stoljeću - kompetencije učenika“, str. 446-453. Poreč: Hrvatski kineziološki savez.

19. Stojanović-Tošić, J., Kostić, R., \& Đorđević, D. (2011). The effects of Kick aerobics on the fitness abilities of female high school studentes. Facta Universitatis, Series: Physical Education and Sport, 9(2), 113-120.

20. Torun Mattsson \& Suzanne Lundvall (2015). The position of dance in physical education. Sport, Education and Society. 20: 855-871 doi.or $\mathrm{g} / 10.1080 / 13573322.2013 .837044$ WHYPERLINK «http://www.tandfonline.com/doi/abs/10.1080/1 3573322.2013.837044»

21. Viskić-Štalec, N; Štalec, J., Katić, R., Podvorac, Đ., Katović, D. (2007). The Impact of Dance-Aerobics Training on the Morpho-Motor Status in Female High-Schoolers. Coll. Antropol. 31 ( 1): 259-266

22. Viski-Stalec, N., Stalec, J., Kati, R., Podvorac, D., \& Katovi, D. (2007). The Dance-Aerobics Training and the Morpho-Motor Status in Female. Coll. Antropol.( 31): 259-266

23. Wang Bei (2016). Research on Body Language in Aerobics Choreography and Physical Education based on Network Questionnaire International. Journal of Future Generation Communication and Networking Vol. 9, No. 4, 207-218 doi. org/10.14257/ijfgen.2016.9.4.18

24. Zubkova T.I. (2006). Features of the use of choreographic exercises when working with students of varying degrees of preparedness. Theory and practice of physical culture. $4: 34$. 


\title{
INFLUENCIA DE LOS PROGRAMAS DE FITNESS A BASE DE BAILE EN LA PREPARACIÓN FÍSICA DE LOS ESTUDIANTES DE LA FACULTAD DE PEDAGOGÍA
}

\begin{abstract}
Resumen
El objeto del presente trabajo es la influencia de los programas de fitness a base de baile en el estatus físico-fitness de los estudiantes (N30) de la Universidad Estatal Jmelnitski Grygor Skovoroda. Los resultados obtenidos son de interés para los enseñadores investigadores en solución del problema de integrar coreografías en la educación física. Sin embargo, es importante destacar que hay una falta en el desarrollo científico-metodológico en esta dirección. Se ha presentado la aplicación de los programas de fitness modernos orientados hacia el baile (danza aeróbica, body ballet, danza del vientre) en la educación física de los estudiantes en las condiciones de conferencias de la facultad. Los resultados de las investigaciones demostraron importantes cambios en los indicadores de entrenamiento físico, salud física, como también en la preparación teórica que sucedieron durante el experimento pedagógico. Se ha establecido que los indicadores de estado físico de los estudiantes en el grupo experimental cambiaron considerablemente como sigue: CxSS indicador aumento de $82,5 \mathrm{~b} / \mathrm{m}$ a 93,03; tensión arterial se mantuvo inalterado, la masa corporal disminuyó de 63,1 a 60,15 kg; la inclinación hacia adelante en la posición sedentaria en $7,77 \mathrm{~cm}(\mathrm{r}<0,05)$; carrera de lanzadera $4 \times 9 \mathrm{~m}$ en $4,82 \mathrm{sec}(\mathrm{r}<0,05)$; levantamiento del cuerpo en un minuto en 4,15 subida $(\mathrm{r}<0,05)$. Se ha establecido que la aplicación de los programas modernos de fitness orientados hacia el baile que se realizan en contexto de la enseñanza universitaria es un modo eficiente de optimizar el programa de la educación física de los estudiantes para que los problemas de su desarrollo físico e intelectual se solucionaran de una manera multifacética, satisfaciendo las necesidades de actividades motrices, pero también para desarrollar una motivación sostenible en las clases de la educación física.
\end{abstract}

Palabras claves; COREOGRAFÍA / DANZA AERÓBICA / BODY BALLET / DANZA DEL VIENTRE/ PREPARACIÓN FÍSICA / PROGRAMAS DE FITNESS / ESTUDIANTES

Примљен: 20. 05. 2018

Прихваћен: 05. 06. 2018 